MS

Editions

BOLETIN LATINOAMERICANO Y DEL CARIBE DE PLANTAS MEDICINALES Y AROMÁTICAS 19 (5): 495 - 507 (2020)

๑) / ISSN 07177917 / www.blacpma.ms-editions.cl

\title{
Chemical constituents of Ocotea paranaensis (Lauraceae) essential oil and their antioxidant, anticancer and antimicrobial properties
}

[Componentes químicos del aceite esencial de Ocotea paranaensis (Lauraceae) y sus propiedades antioxidantes, anticancer y antimicrobianas]

\author{
Caroline Gribner ${ }^{1}$, Paula Francislaine Moura ${ }^{1}$, Andressa Veiga ${ }^{1}$, Larissa Junqueira Gatto ${ }^{1}$, \\ Nayana Cristina da Silva Santos ${ }^{2}$, Francisco de Assis Marques², Ingrid Zattoni ${ }^{3}$, Glaucio Valdameri ${ }^{3,4}$, \\ Josiane de Fatima Gaspari Dias ${ }^{1}$, Obdulio Gomes Miguel $^{1}$ \& Sandra Maria Warumby Zanin ${ }^{1}$ \\ ${ }_{1}^{1}$ Pharmaceutical Sciences Graduate Program, Federal University of Paraná, Curitiba, Brazil \\ ${ }^{2}$ Chemistry Graduate Program, Federal University of Paraná, Curitiba, Brazil \\ ${ }^{3}$ Pharmaceutical Sciences Graduate Program, Laboratory of Cancer Drug Resistance, Federal University of Paraná, Curitiba, Brazil \\ ${ }^{4}$ Department of Clinical Analysis, Federal University of Paraná, Curitiba, Brazil \\ Contactos | Contacts: Caroline GRIBNER - E-mail address: carol_gribner@yahoo.com.br
}

\begin{abstract}
The chemical composition of the essential oil obtained from the branches of Ocotea paranaensis was studied by gas chromatography/mass spectrometry (GC/MS). Twenty-seven compounds, comprising $94.82 \%$ of the total components, were identified. The oil showed relatively high concentration of sesquiterpenes (62.96\%), oxygenated sesquiterpenes (33.33\%), and diterpene (3.70\%). Regarding the major compounds, Z-nerolidol (19.16\%), germacrene D (12.92\%) and $\alpha$-bulnesene $(8.47 \%)$ could be highlighted, which corresponded to $40.55 \%$ of the substances that were found. The essential oil from Ocotea paranaensis has phosphomolybdenum reducing action and is moderately toxic to the Artemia salina $\left(\mathrm{LC}_{50}=147.91 \mu \mathrm{g} / \mathrm{mL}\right)$. It showed haemolytic potential and moderate activity against Staphylococcus aureus, (minimum inhibitory concentration MIC $=250 \mu \mathrm{g} / \mathrm{mL}$ ) and Pseudomonas aeruginosa $(\mathrm{MIC}=500 \mu \mathrm{g} / \mathrm{mL}$ ). No satisfactory cytotoxicity results were observed in lineage H460 and HeLa.
\end{abstract}

Keywords: Lauraceae; Essential oil; Biological properties; Chemical composition.

Resumen: La composición química del aceite esencial obtenido de las ramas de Ocotea paranaensis se estudió por cromatografía de gases/espectrometría de masas (CG/MS). Se identificaron veintisiete compuestos, que comprenden el 94,82\% de los componentes totales. El aceite se caracterizó por una concentración relativamente alta de sesquiterpenos $(62,96 \%)$, sesquiterpenos oxigenados $(33,33 \%)$ y diterpeno $(3,70 \%)$. En cuanto a los compuestos principales, se destacaron Z-nerolidol (19,16\%), germacreno D (12,92\%) y $\alpha$-bulnesene $(8,47 \%)$, que correspondieron al 40,55\% de las sustancias encontradas. El aceite esencial analizado de Ocotea paranaensis tiene una buena acción reductora de fosfomolibdeno y es moderadamente tóxico para la Artemia salina $\left(\mathrm{LC}_{50}=147,91 \mu \mathrm{g} / \mathrm{mL}\right)$. Mostró potencial hemolítico y actividad moderada contra Staphylococcus aureus (concentración inhibitoria mínima MIC $=250 \mu \mathrm{g} / \mathrm{mL}$ ) y Pseudomonas aeruginosa (MIC $=500 \mu \mathrm{g} / \mathrm{mL}$ ). No se observaron resultados satisfactorios de citotoxicidad en el linaje H460 y HeLa.

Palabras clave: Lauraceae; Aceite esencial; Propiedades biológicas; Composición química.

Recibido | Received: November 10, 2019

Aceptado | Accepted: February 29, 2020

Aceptado en versión corregida | Accepted in revised form: April 2, 2020

Publicado en línea | Published online: September 30, 2020

Este artículo puede ser citado como / This article must be cited as: C Gribner, PF Moura, A Veiga, LJ Gatto, NCS Santos, FA Marques, I Zattoni, G Valdameri, JFG Dias, OG Miguel, SMW Zanin. 2020. Chemical constituents of Ocotea paranaensis (Lauraceae) essential oil and their antioxidant, anticancer and antimicrobial properties. Bol Latinoam Caribe Plant Med Aromat 19 (5): 495 - 507. http://doi.org/10.37360/blacpma.20.19.5.34 


\section{INTRODUCTION}

The Lauraceae family is predominantly distributed in tropical and subtropical areas of the Americas, Africa, and eastern Asia. It is composed of trees and bush and it is recognized by about 50 genus with estimated 2500-3000 species. Despite its importance and massive diversity, little information is known about the classification, number, and distribution of the species within the family, which may be related to the difficulty of identification (Van Der Werff \& Richter, 1996).

From the economic point of view, the family (Lauraceae) presents great importance as some of genus such as Ocotea, Cinnamomum, Aniba and Nectandra exhibit various applications. They are used in the manufacturing of culinary products, paper, carpentry and construction. Additionally, they have certain medicinal qualities against various diseases. Ocotea aciphylla, used as an anti-rheumatic and depurative; Ocotea guianensis used in abscesses; Laurus nobilis used as an antispasmodic, against flatulence, wounds and ulcers; Persea american used for kidney problems, diuretic and soothing; Cinnamomum cassia used in colds (Marques, 2001); Dehaasia kurzii and Litsea liyuyingi used in leucorrhoea (Hossan et al., 2010). Chemically, this family is also rich in metabolites, such as neolignans and lignans, aporphine and benzylisoquinoline alkaloids, flavonoids, sesquiterpenes, and pyrones (Garcez et al., 2011).

In Brazil, 22 genus of this family were already found, among them, the genus Ocotea, with about 120-160 species, of which 31 species are found in the Parana State, located in the South region of Brazil (Baitello, 2001; Moraes, 2005; Brotto et al., 2013). The essential oil from these genus have been investigated by several authors along the years, which have been found to demonstrate antiinflammatory, acaricidal, antimicrobial, and antioxidant properties (Chaverri \& Cicció, 2005; Guerrini et al., 2006; Destryana et al., 2014; Moraes et al., 2017).

Recently, one more species called Ocotea paranaensis was discovered in the Atlantic Forest of Parana State and its specific epithet reminds the place where it was first mentioned (Brotto et al., 2010).

This present study aimed to evaluate the chemical composition of the essential oil from branches of Ocotea paranaensis, as well as its antioxidant and biological properties, among them, its haemolytic, antimicrobial and anticancer properties and its toxicity in brine shrimp.

\section{MATERIALS AND METHODS Plant material}

The plant material (branches) were obtained from mature trees in the State Park of Lauraceae, Parana, Brazil, in September 2017, at the following coordinate: Zone 22J, East: 731234.389; North: 7249262.709. The species was identified for comparison by the taxonomist Marcelo Leandro Brotto, under the number MBM 409884. This study was approved by the Brazilian Institute of the Environment (IBAMA) and permission was received to access samples of the genetic patrimony for scientific research purposes and to use and disseminate the results obtained from the botanical material of Ocotea paranaensis, included in Process 02001.001165/2013-47.

\section{Essential oil extraction}

Essential oil (EO) was extracted and obtained from the dried branches of Ocotea paranaensis and the steam distillation process was carried out, using modified Clevenger (Brasil, 2010). Subsequently, the essential oil was separated from the emulsion through decantation using a separating funnel and dried with anhydrous sodium sulfate.

The dried plant material was ground $(600 \mathrm{~g})$ in a knife mill and distilled into the water at $100^{\circ} \mathrm{C}$ for 6 hours. The collected oil was stored in an amber bottle in a freezer at $-18^{\circ} \mathrm{C}$ for later use. The yield was calculated in milliliters of essential oil per $100 \mathrm{~g}$ of the dried plant material (mL\%) (Brasil, 2010).

\section{Chemical analysis: Gas chromatography-mass spectrometry (GC/MS)}

The analysis was performed using a Shimadzu CGMS-QP2010 Plus system equipped with a quadrupole mass detector with a Rtx-5MS (Crossband 5\% diphenyl/95\% dimethylpolysiloxane) low-bleeding column $(30 \mathrm{~m} \times 0.25 \mathrm{~mm} \times 0.25 \mu \mathrm{m})$, where helium was the carrier gas at a flow rate of $1.02 \mathrm{~mL} / \mathrm{min}$. Splitless injection of $1 \mu \mathrm{L}$ of the sample was carried out at an initial oven temperature of $60^{\circ} \mathrm{C}$. The injector and detector temperatures were adjusted to $250^{\circ} \mathrm{C}$. The programmed oven temperature was $60-250^{\circ} \mathrm{C}$ at $3^{\circ} \mathrm{C} / \mathrm{min}$.; EIMS: electron energy, $70 \mathrm{eV}$; ion source temperature and connection parts at $180^{\circ} \mathrm{C}$.

\section{Peak identification}

Individual components were identified by comparing retention indices (RIs) and mass spectra with those of authentic compounds given in the Adams Libraries of mass spectral data and from a computer database 
using Wiley 275, NIST 21, NIST 10733 (NIST, 1998; Adams, 2017).

\section{Antioxidant properties \\ Reduction of Radical DPPH・ (2,2-diphenyl-1- picrylhydrazyl)}

The antioxidant property was evaluated by reducing the DPPH radical according to the adapted methodology (Mensor et al., 2001). Initially, a sample solution of $200 \mu \mathrm{g} / \mathrm{mL}$ was prepared, which was solubilized in methanol with DMSO added to the essential oil in a 1:1 (w/w) ratio. Ascorbic acid, butylated hydroxytoluene (BHT), and rutine - each with a concentration of $200 \mu \mathrm{g} / \mathrm{mL}$ - all solubilized in methanol were used as positive control.

In 96-well flat-bottom microplate, $142 \mu \mathrm{L}$ of the sample and $58 \mu \mathrm{L}$ of the $0.3 \mathrm{mM}$ DPPH solution were added. It was kept for 30 minutes in the dark at $25^{\circ} \mathrm{C}$; then, absorbance readings were performed on a Thermo Scientific ${ }^{\circledR}$ Multiscan FC spectrophotometer at $540 \mathrm{~nm}$.

To eliminate the influence of the staining of the extracts, a blank was prepared for each sample. The blank of the sample was determined using 142 $\mu \mathrm{L}$ of the sample and $58 \mu \mathrm{L}$ of methanol and the negative control $142 \mu \mathrm{L}$ of methanol and $58 \mu \mathrm{L}$ of $\mathrm{DPPH} \bullet$ All assays were performed in triplicate. The ability of essential oil to reduce the DPPH • moiety was calculated from the following equation: \% Inhibition of oxidation of DPPH $=100-[$ (sample absorbance - white absorbance) / (control absorbance - white absorbance)] x 100. The statistical analysis of the results that were obtained was carried out by the ANOVA test and the comparison between the means was verified by the Tukey test, with a $95 \%$ level of significance. The Sisvar software was used to perform these analyses.

\section{Formation of the Phosphomolybdenum Complex}

The antioxidant property was evaluated by reduction of the phosphomolybdenum complex according to the adapted methodology (Prieto et al., 1999). For the performance of this assay, the essential oil and standards (ascorbic acid, BHT, and rutin) solutions were prepared at the concentration of $200 \mu \mathrm{g} / \mathrm{mL}$. The essential oil was diluted in methanol and DMSO (1:1), while the positive controls were diluted only in methanol. The reagent was prepared at the time of use, which consisted of a 0.6 mol.L $\mathrm{L}^{-1}$ aqueous sulfuric acid solution, $28 \mathrm{mmol} . \mathrm{L}^{-1}$ sodium phosphate, and 4 mmol. $\mathrm{L}^{-1}$ ammonium molybdate.

In triplicate, $3 \mathrm{~mL}$ of reagent and $0.3 \mathrm{~mL}$ of the essential oil and standard were added to a test tube. The tubes were capped and taken to a water bath for $90 \mathrm{~min}$ at $95^{\circ} \mathrm{C}$. After cooling, the samples were transferred to 96-well microplates for absorbance readings on a Multiscan FC Thermo Scientific ${ }^{\circledR}$ spectrophotometer at a wavelength of 690 nm.

To evaluate the antioxidant capacity of essential oil, the relative antioxidant activity (AAR\%) was calculated, taking into account the positive standards, ascorbic acid, BHT, and rutin, from the following equation: AAR $(\%)=[$ (sample absorbance - white absorbance)/(standard absorbance - white absorbance)] x 100. The statistical analysis of the results was carried out by the ANOVA test and the comparison between the means was verified by the Tukey test, with a 95\% level of significance. The Sisvar software was used to perform these analyses.

\section{Biological properties}

\section{Toxic activity in Artemia salina}

The evaluation of toxicity against Artemia salina was done by following the methodology (Meyer et al., 1982; Martinez et al., 1997) with some adaptations.

Initially, artificial seawater was prepared by dissolving $38 \mathrm{~g}$ of sea salt (Blue Treasure ${ }^{\circledR}$ ) in $1 \mathrm{~L}$ of distilled water and adjusting its $\mathrm{pH}$ to 9.0 with $\mathrm{Na}_{2} \mathrm{CO}_{3}$ (Meyer et al., 1982). Saline brine shrimp eggs $(200 \mathrm{mg} / 400 \mathrm{~mL})$ hatched in artificial seawater for 48 hours under continuous aeration while being exposed to constant light under controlled temperature $\left(27\right.$ to $\left.30^{\circ} \mathrm{C}\right)$ to $\mathrm{pH} 8-9$. The negative control (white) was a saline solution and the positive control quinidine sulfate.

The essential oil was prepared in triplicate with different concentrations $(10,100,250,500$, and $1000 \mu \mathrm{g} / \mathrm{mL}$ ) and solubilized in polysorbate 80 in $1: 1$ (w/w) ratio in methanol; the solvent evaporated by 24 hours at $37^{\circ} \mathrm{C}$ and the volume of artificial seawater filled up to $5 \mathrm{~mL}$.

To evaluate the toxicity, 10 larvae of Artemia saline were transferred to glass vials containing the essential oil and controls. Subsequently, the flasks were incubated at room temperature for 24 hours. After this period, it was possible to count dead and alive larvae. As a negative control, the larvae were evaluated against methanol solvent plus polysorbate 80 at a ratio of $1: 1(\mathrm{w} / \mathrm{w})$; the positive control quinidine sulfate was used at the same concentrations that were prepared for the samples. Their preparation was performed as described for the essential oil.

The results are expressed as $\mathrm{LC}_{50}$ (lethal 
concentration for $50 \%$ of the individuals) and $95 \%$ confidence intervals. For the calculation, the statistical program Probitos was applied using the IBM SPSS Statistics ${ }^{\circledR}$ software.

\section{Haemolytic activity in vitro}

The evaluation of haemolytic activity was performed, based on the methodology described by Benerjee et al. (2008), with adaptations. Defibrinated ram blood $\left(\right.$ Newprov $\left.^{\circledR}\right)$ was prepared to obtain a diluted erythrocyte pope with phosphate-saline buffer (PBS) to $2 \%$ (w/v) (Banerjee et al., 2008).

For the haemolysis test, the saponin standard and the essential oil were prepared at concentrations of $1000,750,500,250$, and $100 \mu \mathrm{g} / \mathrm{mL}$. Preparation of the $1000 \mu \mathrm{g} / \mathrm{mL}$ saponin solution was performed in $10 \%$ methanol and PBS. $0.5 \%$ (v/v) DMSO was added only for the preparation of the essential oil. As a negative control, $200 \mu \mathrm{L}$ PBS was used in $200 \mu \mathrm{L}$ $2 \%$ erythrocyte solution; negative controls of the solvents were performed with PBS in $10 \%$ methanol and PBS with $0.5 \%(\mathrm{v} / \mathrm{v})$ DMSO. As positive control water, $200 \mu \mathrm{L}$ of potable water was used in $200 \mu \mathrm{L}$ of $2 \%$ erythrocyte solution. As positive control, Triton was used as $200 \mu \mathrm{L}$ of $1 \%$ triton in $200 \mu \mathrm{L}$ of $2 \%$ erythrocyte solution. The assay was performed on Eppendorf and incubated for 3 hours at $37^{\circ} \mathrm{C}$ controlled temperature. After incubation, the solutions were centrifuged at $3000 \mathrm{rpm}$ for 5 minutes.

Haemolysis was assessed by reading the displayed absorbance of the supernatant in a Multiscan FC Thermo Scientific ${ }^{\circledR}$ microplate reader adjusted to $540 \mathrm{~nm}$. For the quantification of haemolysis, the value was calculated as a percentage, considering the value of $100 \%$ the absorbance read in the total haemolysis tube and using $1 \%$ triton and potable water as reference.

Using linear regression, the concentration that is required to achieve $50 \%$ haemolytic activity was determined. The statistical analysis of the results was conducted using the ANOVA test and the comparison between the means was verified by the Tukey test, with a 95\% level of significance. The Sisvar software was used to perform these analyses.

\section{Antimicrobial activity}

Antimicrobial activity was assessed by determining Minimum Inhibitory Concentration (MIC) using the microdilution method according to the CLSI (2008), which was standardized and validated by Veiga et al. (2019). Standard strains of the bacteria Staphylococcus aureus (ATCC 6538), Pseudomonas aeruginosa (ATCC 9027), Escherichia coli (ATCC 8738), and Candida albicans (ATCC 10231) were used.

Initially, the inoculum was prepared in $0.9 \%$ saline. Subsequently, turbidity was standardized to 0.5 Mc Farland using the DEN-1 Biosan ${ }^{\circledR}$ densitometer. The broth microdilution technique was performed on sterile 96-well U-bottom plastic microplates. All samples were tested in triplicate by placing only one microorganism per plate.

The sample was prepared at $1 \mathrm{mg} / \mathrm{mL}$ in $5 \%$ DMSO distilled water and serially diluted in Muller Hinton Broth (MHB - Merck, Darmstadt, Germany) for bacteria and Sabouraud Dextrose broth for yeast. Concentrations ranged from $500 \mu \mathrm{g} / \mathrm{mL}-3.9 \mu \mathrm{g} / \mathrm{mL}$. $10 \mu \mathrm{L}$ of the previously prepared bacterial suspensions were inoculated into all wells except the blank. Negative control was performed by adding $100 \mu \mathrm{L}$ of the sample diluent solution to $100 \mu \mathrm{L}$ of broth and $10 \mu \mathrm{L}$ of inoculum. In the white wells of the sample, $100 \mu \mathrm{L}$ of broth and $100 \mu \mathrm{L}$ of the sample that was to be tested (essential oil) were used. To demonstrate that the technique is effective and to confirm the lack of resistance of microorganisms to the drugs that were used, positive control with 100 $\mu \mathrm{L}$ broth, $100 \mu \mathrm{L}$ antimicrobial solution (chloramphenicol $250 \mu \mathrm{g} / \mathrm{mL}$ for bacteria and ketoconazole $500 \mu \mathrm{g} / \mathrm{mL}$ for yeast) and $10 \mu \mathrm{L}$ of the inoculum was performed.

The microplate incubation was performed in a bacteriological oven at a constant temperature of $35^{\circ} \mathrm{C}$ for 22 hours. Then, $20 \mu \mathrm{L}$ of $0.125 \% 2,3,5-$ triphenyl tetrazolium chloride developer (TTC Merck, Darmstadt, Germany) was added and the microplates were incubated again for two hours at $35^{\circ} \mathrm{C}$. The development of red/pink coloration was interpreted as cell growth, as TTC (colorless) is reduced by the metabolism of microorganisms, thereby becoming a compound with coloration. Results were classified as good antibacterial activity (up to $100 \mu \mathrm{g} / \mathrm{mL}$ ), moderate activity (between 100$500 \mu \mathrm{g} / \mathrm{mL}$ ), weak activity (between 500-1000 $\mu \mathrm{g} / \mathrm{mL}$ ) and inactive (greater than $1000 \mu \mathrm{g} / \mathrm{mL}$ ) (Ayres et al., 2008; Santos et al., 2008).

To evaluate the Minimum Fungicidal Concentration (CFM) and the Minimum Bactericidal Concentration (CBM), the technique of Santurio et al. (2007) was used with modifications. In duplicate, 100 $\mu \mathrm{L}$ of a specimen that was positive for antimicrobial activity was transferred to plates containing TSA agar (bacteria) and Sabouraud agar (yeast). Afterward, the plates were incubated for 22 hours at $35^{\circ} \mathrm{C}$. Lack of 
growth indicated the bactericidal action of the tested sample and colony growth indicated the bacteriostatic action of the tested sample (Santurio et al., 2007).

\section{Antiproliferative activity}

H460 (lung cancer) and HeLa (human uterine carcinoma) cell lines were grown in medium DMEM (Dulbecco's Modified Eagle Medium) high glucose, supplemented with $10 \%$ of fetal bovine serum and $1 \%$ of antibiotic. Cells were grown in a cell culture incubator with controlled humid atmosphere which contained $5 \%$ of $\mathrm{CO}_{2}$ at $37^{\circ} \mathrm{C}$. Cell viability was assessed by reducing MTT tetrazolium salt bromide [3-(4,5-dimethylthiazol-2-yl)-2,5-diphenyltetrazolium] (yellow) to formazan (purple), which was quantified by spectrophotometry (Mosmann, 1983).

In brief, cells were plated in 96-well plates at $1.0 \times 10^{4}$ cells/well for $\mathrm{H} 460$ cells and $1.5 \times 10^{4}$ cells/well for HeLa cells. Cells were kept in a cell culture incubator for 24 hours for adhesion. Then, the cells were treated with the essential oil at 10 and $50 \mu \mathrm{g} / \mathrm{mL}$, respectively, for 72 hours. The control condition corresponding to $100 \%$ of the viable cells was performed with culture medium containing $0.1 \%$ of DMSO (v/v). The results were expressed as a percentage of viable cells that was relative to the control condition. After treatment, the supernatant was removed. $100 \mu \mathrm{L}$ of [3-(4,5-dimethylthiazol- 2-yl)-2,5diphenyltetrazolium bromide] (MTT) $(0.5 \mathrm{mg} / \mathrm{mL})$ was added, which was incubated for 4 hours in the dark at $37^{\circ} \mathrm{C}$. Then, the MTT solution was removed and the formazan crystals were eluted with $100 \mu \mathrm{L}$ of DMSO/ethanol solution (1:1). Absorbances were read on a Thermo Scientific ${ }^{\circledR}$ Multiscan FC spectrophotometer at $570 \mathrm{~nm}$. The assays were performed as independent replicates and the graphs showing the mean \pm SD results were created using the GraphPad Prism 5 software.

Figure No. 1

Abundant compounds identified in essential oil of Ocotea paranaensis<smiles>C=CC(C)(O)CCC=C(C)CCC=C(C)C</smiles>

$Z$-nerolidol<smiles>C=C1/C=C/[C@H](C(C)C)CCC(C)/C=C\C1</smiles>

Germacrene-D

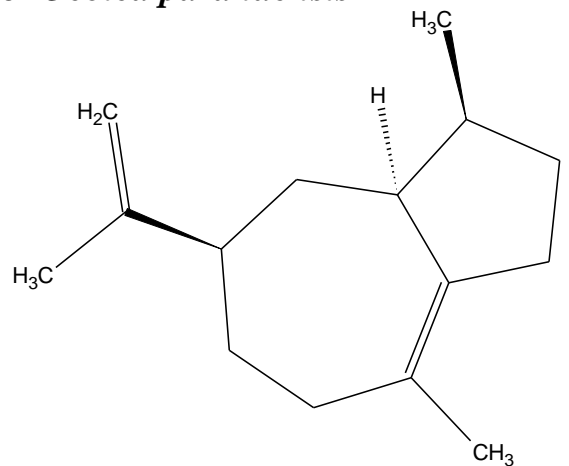

a-bulnesene

TABLE No. 1

Identification of compounds in essential oil from Ocotea paranaensis by GC-MS

\begin{tabular}{|c|c|c|c|c|c|c|}
\hline CAS & RT & IA & IAt & Compounds & {[] \% } & Classification \\
\hline $20307-84-0$ & 20.160 & 1336 & 1335 & $\delta$-Elemene & 0.58 & Sesquiterpene \\
\hline $17699-14-8$ & 20.665 & 1348 & 1348 & $\alpha$-Cubebene & 5.43 & Sesquiterpene \\
\hline $14912-44-8$ & 21.575 & 1370 & 1373 & $\alpha$-Ylangene & 0.51 & Sesquiterpene \\
\hline $3856-25-5$ & 21.755 & 1375 & 1374 & $\alpha$-Copaene & 1.04 & Sesquiterpene \\
\hline $18252-44-3$ & 22.350 & 1389 & 1430 & $\beta$-Copaene & 1.81 & Sesquiterpene \\
\hline $515-13-9$ & 22.425 & 1391 & 1389 & $\beta$-Elemene & 1.97 & Sesquiterpene \\
\hline $87-44-5$ & 23.535 & 1418 & 1417 & E-Caryophyllene & 5.02 & Sesquiterpene \\
\hline $29873-99-2$ & 24.110 & 1432 & 1434 & $\gamma$-Elemene & 0.6 & Sesquiterpene \\
\hline $6753-98-6$ & 24.905 & 1452 & 1452 & $\alpha$-Humulene & 1.7 & Sesquiterpene \\
\hline $30021-74-0$ & 25.855 & 1476 & 1478 & $\gamma$-Muurolene & 0.71 & Sesquiterpene \\
\hline $23986-74-5$ & 26.025 & 1480 & 1484 & Germacrene D & 12.92 & Sesquiterpene \\
\hline- & 26.450 & 1490 & & & 0.95 & Sesquiterpene \\
\hline $21747-46-6$ & 26.605 & 1494 & 1496 & Viridiflorene & 0.65 & Sesquiterpene \\
\hline $99529-78-9$ & 26.650 & 1495 & 1498 & $\beta$-Alaskene & 2.78 & \\
\hline
\end{tabular}




\begin{tabular}{|c|c|c|c|c|c|c|}
\hline $31983-22-9$ & 26.805 & 1499 & 1500 & $\alpha$-Muurolene & 0.61 & Sesquiterpene \\
\hline $39029-41-9$ & 27.335 & 1513 & 1513 & $\gamma$-Cadinene & 1.35 & Sesquiterpene \\
\hline $483-76-1$ & 27.705 & 1523 & 1522 & $\delta$-Cadinene & 4.97 & Sesquiterpene \\
\hline- & 28.605 & 1546 & & NI & 1.1 & \\
\hline $3691-11-0$ & 28.990 & 1556 & 1509 & $\alpha$-Bulnesene & 8.47 & Sesquiterpene \\
\hline $142-50-7$ & 29.260 & 1563 & 1531 & Z-Nerolidol & 19.16 & Oxygenated sesquiterpene \\
\hline $6750-60-3$ & 29.780 & 1577 & 1577 & Spathulenol & 5.4 & Oxygenated sesquiterpene \\
\hline $1139-30-6$ & 29.980 & 1582 & 1582 & Caryophylene oxide & 4.71 & Oxygenated sesquiterpene \\
\hline 489-86-1 & 30.560 & 1598 & 1600 & Guaiol & 1.26 & Oxygenated sesquiterpene \\
\hline $5937-11-1$ & 31.710 & 1629 & 1638 & $\alpha$-epi-Cadinol & 3.99 & Oxygenated sesquiterpene \\
\hline $481-34-5$ & 32.210 & 1642 & 1652 & $\alpha$-Cadinol & 3.56 & Oxygenated sesquiterpene \\
\hline- & 32.365 & 1647 & & NI & 0.74 & \\
\hline $28400-11-5$ & 32.660 & 1655 & 1636 & $\beta$-Acorenol & 2.77 & Oxygenated sesquiterpene \\
\hline $22451-73-6$ & 33.130 & 1668 & 1670 & Bulnesol & 1.44 & Oxygenated sesquiterpene \\
\hline $1209-91-2$ & 33.550 & 1679 & 1676 & Mustakone & $\overline{0.4}$ & Oxygenated sesquiterpene \\
\hline- & 36.615 & 1766 & & NI & 0.56 & \\
\hline $34424-57-2$ & 45.420 & 2036 & 2042 & Kaurene & 1.01 & Diterpene \\
\hline \multicolumn{2}{|c|}{ Identified } & & & & 94.82 & Identified \\
\hline \multicolumn{2}{|c|}{ Diterpene } & & & & 3.70 & Diterpene \\
\hline \multicolumn{2}{|c|}{ Oxygenated sesquiterpenes } & & & & 33.33 & Oxygenated sesquiterpenes \\
\hline \multicolumn{2}{|c|}{ Sesquiterpenes } & & & & 62.96 & Sesquiterpenes \\
\hline \multicolumn{2}{|c|}{ Unidentified } & & & & 3.35 & Unidentified \\
\hline
\end{tabular}

$\mathrm{RT}=$ retention time (minutes), IAt $=$ theoretical arithmetic index (Adams, 2017), IA = calculated arithmetic index, [ ] $\%=$ component percentage. $\mathrm{NI}=$ Not identified.

\section{RESULTS AND DISCUSSION}

Ocotea paranaensis essential oil obtained through Clevenger hydrodistillation was light green and its yield was $0.1 \%$, calculated in milliliters of essential oil per $100 \mathrm{~g}$ of dried plant material (mL\%) (Brasil, 2010).

The yield presented by Ocotea paranaensis is an expected value for essential oils of this genus, as already noted in Ocotea ceanothifolia $(0.07 \%)$, Ocotea leucoxylon $(0.05 \%)$, Ocotea minor $(0.04 \%)$ (Yamaguchi, 2011), and Ocotea porous $(0.08 \%)$ (Brito, 2009). Yields with high essential oil content were reported in Ocotea duckei, which presented a yield of $1.0 \%$ for branch oil (Barbosa-Filho et al., 2008).

The different yields in species of the same genus may be related to geographical and environmental factors, such as temperature, light intensity, stage of development, humidity (Sangwan et al., 2001; Destryana et al., 2014;), as well as the plant material that was used and harvest time (Barbosa-Filho et al., 2008). The results of GC/MS analyses are listed in Table No. 1.

A total of 27 compounds (94.82\%) were identified, of which sesquiterpenes $(62.96 \%)$ were predominant, followed by oxygenated sesquiterpenes $(33.33 \%)$ and diterpene $(3.70 \%)$. The predominance of sesquiterpenes has already been evidenced in other
Ocotea species (Takaku et al., 2007; Damasceno et al., 2017). Regarding the majorities, Z-nerolidol $(19.16 \%)$, germacrene D $(12.92 \%)$, and $\alpha$-bulnesene $(8.47 \%)$ can be highlighted, corresponding to $40.55 \%$ of the compounds found (Figure No. 1). No compounds below $0.4 \%$ were identified, which represented $3.35 \%$ of the sample analyzed.

When the composition of essential oils of the genus Ocotea was evaluated, a wide variety of chemical constituents were observed. In the analysis of essential oils from ten species of Ocotea (Lauraceae), Monteverde and Costa Rica, the primary common constituents were $\alpha$-pinene, $\beta$-pinene, $\beta$ caryophyllene, and germacrene-D (Takaku et al., 2007). Germacrene-D in Ocotea caudata is one of the predominant substances of essential oils obtained from branches and leaves (Da Silva et al., 2017). Several oils that have germacrene-D in their composition are reported to possess antimicrobial properties (Sousa et al., 2008; Goren et al., 2011).

Additionally, the presence of nerolidol in Ocotea tonduzii, Ocotea valeriana, Ocotea varaguensis, and Ocotea whitei was also evidenced (Takaku et al., 2007). Nerolidol is an oxygenated sesquiterpene that is present in various floral-scented plants and is widely used as a fragrance in cosmetics and toiletries (Lapczynski et al., 2008). It has a variety of biological properties, such as antioxidant, 
antibacterial, anti-biofilm, antifungal, and antitumor (Brehm-Stecher \& Johnson, 2003; Chan et al., 2016). The presence of $\alpha$-bulnesene has already been evidenced in other genus of the Lauraceae family. It is a sesquiterpene that inhibits platelet aggregation (Hsu et al., 2006). In Nectandra salicina, twigs and leaves were analyzed, which presented $0.1 \%$ and $<0.05 \% \alpha$-bulnesene, respectively (Cicció et al., 2009).

The potential for antioxidants in natural products is widely evaluated to discover the mechanisms involved that contribute to a wide variety of biological properties. Compounds that exhibit this activity can protect biological systems from harmful effects caused by the excess formation of reactive oxygen species (Alam et al., 2013; LópezAlarcón \& Denicola, 2013).

The activity of antioxidants in reducing the $\mathrm{DPPH} \cdot$ radical that was obtained for oil essential Ocotea paranaensis is described in Table No. 2. The $\mathrm{DPPH} \bullet$ molecule is characterized as a stable free radical having an unpaired electron, which causes violet staining. When this free radical comes into contact with a substrate (HA) that can donate a hydrogen atom due to oxidoreduction, the formation of a reduced colorless form occurs (Mensor et al., 2001; Alam et al., 2013). From the absorbance readings obtained for the analyzed sample, the ability to reduce the $\mathrm{DPPH} \bullet$ radical was calculated. From preliminary tests, it was found that the $\mathrm{IC}_{50}$ of the essential oil would be above $1000 \mu \mathrm{g} / \mathrm{mL}$, so it was decided to perform the test only at a concentration of $200 \mu \mathrm{g} / \mathrm{mL}$. Thus, the analyzed sample presented low antioxidant activity against $\mathrm{DPPH} \cdot$, when compared to controls that are tested at the same concentration.

Samples with more polar characteristics are expected to have higher antioxidant activity, as they have more hydroxyl groups. Besides, the structural conformation of compounds that interact with the reaction site also contributes to the development of the reaction (Brand-Williams et al., 1995; Mensor et al., 2001). Such arguments justify the results that were obtained, because the sample has a nonpolar character and a larger amount of non-hydroxyl constituents.

Table No. 2

Antioxidant activity of Ocotea paranaensis essential oil

\begin{tabular}{|c|c|c|c|c|c|}
\hline \multicolumn{2}{|c|}{ Method } & $\begin{array}{l}\text { Essential oil } \\
(200 \mu \mathrm{g} / \mathrm{mL})\end{array}$ & $\begin{array}{c}\text { Ascorbic acid } \\
(200 \mu \mathrm{g} / \mathrm{mL})\end{array}$ & $\begin{array}{c}\text { BHT } \\
(200 \mu \mathrm{g} / \mathrm{mL})\end{array}$ & $\begin{array}{c}\text { Rutin } \\
(200 \mu \mathrm{g} / \mathrm{mL})\end{array}$ \\
\hline & Mean \pm SD & Mean \pm SD & Mean \pm SD & Mean \pm SD \\
\hline \multicolumn{2}{|c|}{ DPPH• scavenging (\%) } & $15.54 \pm 0.89^{a}$ & $99.42 \pm 0.38^{c}$ & $95.68 \pm 0.25^{b}$ & $95.97 \pm 0.25^{b}$ \\
\hline \multirow{3}{*}{$\begin{array}{c}\text { Phosphomolybdenum } \\
\text { complex AAR (\%) }\end{array}$} & $\begin{array}{c}\text { Related to } \\
\text { Ascorbic acid }\end{array}$ & $74.95 \pm 1.42^{\mathrm{a}}$ & $100^{\mathrm{b}}$ & - & - \\
\hline & Related to BHT & $175.96 \pm 3.33^{b}$ & - & $100^{\mathrm{a}}$ & - \\
\hline & Related to Rutin & $406.49 \pm 7.71^{\mathrm{b}}$ & - & - & $100^{\mathrm{a}}$ \\
\hline
\end{tabular}

(1) AAR\% (Percent relative antioxidant activity), SD (standard deviation); Means followed by equal letters do not differ according to the Tukey test $(p<0.05)$.

However, the antioxidant potential based on the reduction of the phosphomolybdenum complex showed a different profile (Table No. 2). The best result was observed in comparison with the rutin standard (406.49\%), followed by BHT (175.96\%), which in turn demonstrated that the essential oil has phosphomolybdenum reducing action. The principle of this essay is based on the reduction of molybdenum VI to molybdenum $\mathrm{V}$ when exposed to lipophilic or hydrophilic substances with antioxidant properties, which results in a green-colored phosphomolybdenum complex (Prieto et al., 1999). In the evaluation of toxicity against Artemia salina, the Ocotea paranaensis essential oil presented an $\mathrm{LC}_{50}$ of $147.91 \mu \mathrm{g} / \mathrm{mL}$ (Table No. 3), whereas the quinidine control presented an $\mathrm{LC}_{50}$ of $116.01 \mu \mathrm{g} / \mathrm{mL}$. Thus, it can be suggested that the essential oil is moderately bioactive against Artemia salina, since the $\mathrm{LC}_{50}$ value obtained for the essential oil is between 100 and $500 \mu \mathrm{g} / \mathrm{mL}$ (Amarante et al., 2011), which allows correlation with other potential biological activities. 
TABLE No. 3

Determination of the $\mathrm{LC}_{50}$ of the essential oil of Ocotea paranaensis by the bioassay in Artemia salina

\begin{tabular}{l|c|c|c|c|c|cc}
\multicolumn{1}{c}{ SAMPLE } & MORTALITY Artemia test 24h & LC $_{\mathbf{5 0}}\left(\boldsymbol{\mu g} . \mathbf{m L}^{-\mathbf{1}}\right)$ & CI 95\% $\left(\boldsymbol{\mu g} . \mathbf{m L}^{-1}\right)$ \\
\hline Concentration $\left(\mu \mathrm{g} . \mathrm{mL}^{-1}\right)$ & 10 & 100 & 250 & 500 & 1000 & & \\
Essential oil & 0 & 7 & 25 & 30 & 30 & 147,91 & $120,063177,66$ \\
& & & & & & & \\
Methanol & 0 & 0 & 0 & 0 & 0 & $>1000$ & - \\
Quinidine & 0 & 10 & 30 & 30 & 30 & 116,01 & $94,39-139,70$ \\
\hline
\end{tabular}

LC $_{50}=$ Lethal concentration to $50 \%$, CI 95\% $=95 \%$ confidence interval

The toxic potential of oils extracted from the genus Ocotea can be observed in other species, such as Ocotea notata, which presented an $\mathrm{LC}_{50}$ of 2.37 $\mu \mathrm{g} / \mathrm{mL}$ (Garrett et al., 2007), and as observed in Ocotea nutans, which presented an $\mathrm{LC}_{50}$ of 71.70 $\mu \mathrm{g} / \mathrm{mL}$ (Betim et al., 2019). Based on the results shown in Table No. 3, we can say that the essential oil from the Ocotea paranaensis branches showed haemolytic activity (to potable water and $1 \%$ triton respectively: $\quad \mathrm{IC}_{50} \quad 313.30 \mu \mathrm{g} / \mathrm{mL} ; \quad \mathrm{IC}_{50} \quad 294.62$ $\mu \mathrm{g} / \mathrm{mL}$ ). Saponin was used as a positive control of haemolytic action evaluation, as it produces alterations in the erythrocyte membrane and, consequently, leads to the rupture and release of hemoglobin (Manaargadoo-catin et al., 2016).

Table No. 4

Evaluation of the essential oil haemolytic activity of the Ocotea paranaensis

\begin{tabular}{|c|c|c|c|c|c|}
\hline \multirow{3}{*}{ Sample } & \multirow{3}{*}{$\begin{array}{c}\text { Concentration } \\
\mu \mathrm{g} / \mathrm{mL}\end{array}$} & \multicolumn{4}{|c|}{ \% Haemolysis } \\
\hline & & \multicolumn{2}{|c|}{ Triton 1\% } & \multicolumn{2}{|c|}{ Potable water } \\
\hline & & Mean \pm SD & Test Tukey $^{1}$ & Mean \pm SD & TestTukey $^{1}$ \\
\hline \multirow{5}{*}{ Saponin } & 100 & $21,21 \pm 1,08$ & a3 a4 & $20,50 \pm 1,05$ & a4 a5 \\
\hline & 250 & $69,82 \pm 3,35$ & a8 & $67,48 \pm 3,24$ & a9 \\
\hline & 500 & $85,53 \pm 0,76$ & a9 & $82,67 \pm 0,74$ & a10 \\
\hline & 750 & $88,18 \pm 3,17$ & a9 & $85,22 \pm 3,06$ & a10 \\
\hline & 1000 & $89,24 \pm 1,99$ & a9 & $86,25 \pm 1,91$ & a10 \\
\hline \multirow{5}{*}{ Essential oil } & 100 & $35,74 \pm 0,87$ & a5 a6 & $34,54 \pm 0,84$ & a6 a7 \\
\hline & 250 & $42,56 \pm 0,75$ & a6 a7 & $41,13 \pm 0,72$ & a7 a8 \\
\hline & 500 & $66,83 \pm 2,56$ & a8 & $64,59 \pm 2,47$ & a9 \\
\hline & 750 & $92,7 \pm 1,07$ & a9 & $89,59 \pm 1,03$ & a10 a11 \\
\hline & 1000 & $113,35 \pm 5,73$ & a11 & $115,2 \pm 9,89$ & a12 \\
\hline
\end{tabular}

(1) Means followed by equal letters do not differ according to the Tukey test $(p<0.05)$

Within in vitro haemolysis of medicinal plants, samples are widely used for preliminary toxicity studies (Pequeno \& Soto-Blanco, 2006), which may be related to erythrocytic membrane instability concerning plant extracts (Sharma \& Sharma, 2001). As a consequence of elevated hemoglobin in the plasma due to red cell lysis, detrimental effects can be evidenced mainly in the kidneys and cardiovascular system (Carvalho et al., 2007).
Analysis of essential oils from other genus of the Lauraceae family, such as Cinnamomum zeylanicum, reports the osmotic fragility of red blood cells when exposed to the oil that is obtained from the barks, possibly due to morphological and structural alterations of erythrocytes (Barros et al., 2016).

Regarding antimicrobial activity (Table No. 5), the oil exhibited higher activity against Staphylococcus aureus with MIC of $250 \mu \mathrm{g} / \mathrm{mL}$. It 
also showed activity against Pseudomonas aeruginosa with a MIC of $500 \mu \mathrm{g} / \mathrm{mL}$. The bacteriostatic effect was observed for both microorganisms. For Candida albicans and Escherichia coli, there was no activity until the highest concentration tested, $500 \mu \mathrm{g} / \mathrm{mL}$.

Table No. 5

Minimum inhibitory concentration (MIC) $(\mu \mathrm{g} / \mathrm{mL})$ of the essential oil of Ocotea paranaensis

\begin{tabular}{cc}
\hline Microorganism & MIC $(\boldsymbol{\mu g} / \mathbf{m L})$ \\
\hline Candida albicans & $>500$ \\
Pseudomonas aeruginosa & 500 \\
Staphylococcus aureus & 250 \\
Escherichia coli & $>500$ \\
\hline
\end{tabular}

The composition of Ocotea paranaensis oil suggests its antimicrobial potential. Nerolidol, its main constituent, has antibacterial and antifungal properties (Chan et al., 2016). Another constituent that also has antimicrobial properties is germacreneD (Sousa et al., 2008; Goren et al., 2011).

When compared to other species of the same genus, the essential oil presented higher activity than that found in Ocotea nutans, which in turn showed MIC of $1000 \mu \mathrm{g} / \mathrm{mL}$ against Staphylococcus aureus and Pseudomonas aeruginosa (Betim et al., 2019). The antimicrobial properties of other species from genus Ocotea have good results for different microorganisms. Ocotea quixos demonstrated excellent results with flower and leaf calyx oils against Staphylococcus aureus, Enterococcus faecalis, Pseudomonas aeruginosa, Escherichia coli, and Candida albicans (Chaverri et al., 2011). In Ocotea bofo, the results obtained from bacterial strains showed a higher sensitivity to Escherichia coli, Staphylococcus aureus, and Bacillus subtilis, while Pseudomonas aeruginosa was not affected by the oil (Guerrini et al., 2006). Essential oils from other genus of the Lauraceae family, such as Nectandra megapotamica, have also proved to be active against Staphylococcus aureus and Pseudomonas aeruginosa (Apel et al., 2006).

Given the variety of compounds that make up the essential oil, the mechanism of action in different microorganisms may involve multiple targets in the bacterial cell. The hydrophobicity of the oils makes them permeable to the cell membrane, thereby resulting in the extravasation of the cell contents. Gram-negative bacteria are less sensitive to volatile oils than Gram-positive bacteria (Pintore et al., 2002) and may be related to the presence of lipopolysaccharides in the membrane, which would hinder the diffusion of hydrophobic compounds present in volatile oils (Burt, 2004; Apel et al., 2006).

Figure No. 2

Antiproliferative activity of Ocotea paranaensis essential oil

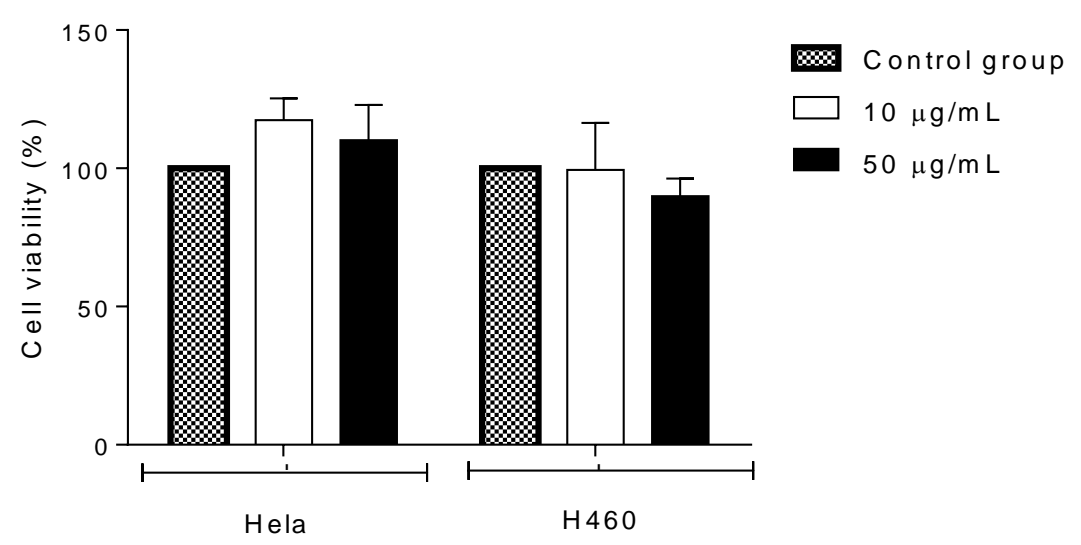

Boletín Latinoamericano y del Caribe de Plantas Medicinales y Aromáticas/503 
In order to further investigate the biological activities of this essential oil, the test for anticancer activity was carried out using two different cancer cells. The human lung cancer (H460) and a human uterine carcinoma (HeLa) cell lines were exposed to the essential oil for $72 \mathrm{~h}$ at 10 and $50 \mu \mathrm{g} / \mathrm{mL}$. As shown in figure 2 , any cytotoxic effect was observed, even in higher concentrations. Despite some studies proposing that oil concentrations between 10-50 $\mu \mathrm{g} / \mathrm{mL}$ can inhibit cell growth, oils present a very low cytotoxic effect (Sylvestre et al., 2006; Niksic et al., 2019). The in vitro cytotoxicity of essential oils is related to the specific components that are present in its composition (Niksic et al., 2019). The low cytotoxic effect against $\mathrm{H} 460$ cells was reported for Ocotea gomezii $\left(\mathrm{LD}_{50}\right.$ of $160 \mu \mathrm{g} / \mathrm{mL}$ for leaves; 119 $\mu \mathrm{g} / \mathrm{mL}$ for bark and $414 \mu \mathrm{g} / \mathrm{mL}$ for wood) and Ocotea morae ( $\mathrm{LD}_{50}$ of $353 \mu \mathrm{g} / \mathrm{mL}$ for leaves; $139 \mu \mathrm{g} / \mathrm{mL}$ for bark and $218 \mu \mathrm{g} / \mathrm{mL}$ for wood), which have different compounds in the essential oils of leaves, bark, and wood (Chaverri et al., 2011). Moreover, a low cytotoxicity was also reported by the Lauraceae family. The essential oil of Nectandra leucantha leaves showed a $\mathrm{LD}_{50}$ of $60 \mu \mathrm{g} / \mathrm{mL}$ against $\mathrm{HeLa}$ cells (Grecco et al., 2015).

Terpenoids in essential oils prevent the proliferation of tumor cells by necrosis or apoptosis induction. Also, they may have antioxidant potential, which reduces oxidative stress that is characteristic of the development of malignant tumors (Raut \& Karuppayil, 2014). Germacrene-D, one of the main substances found in Ocotea paranaensis branch oil, presents cytotoxicity against leukemia tumor cells (HL-60) and shows lower selectivity concerning healthy cells. When present in mixtures, they are usually associated with observed cytotoxic effects (Silva et al., 2013). However, as it is a complex combination of chemical constituents, each substance can modulate and contribute to the effects of other compounds. As a consequence of synergism, the study of isolated substances may not match studies performed with mixtures containing a certain known activity compound (Wright et al., 2007).

\section{CONCLUSION}

The chemical characterization of the essential oil of Ocotea paranaensis branches allowed us to identify a total of 27 compounds (94.82.10\%), including ZNerolidol (19.16\%), Germacrene D (12.92\%), and $\alpha$ Bulnesene $(8.47 \%)$, which corresponds to $40.55 \%$ of the compounds found.

Regarding its properties, the analyzed sample showed antioxidant potential, toxicity to brine shrimp, hemolytic and antimicrobial potential. These results direct further studies to explore other activities and the use of this essential oil.

\section{ACKNOWLEDGEMENTS}

This work was carried out with the support of the Coordination of Improvement of Higher Education Personnel - Brazil (CAPES) - Financing Code 001. The authors are thankful to the Commission for the Improvement of Higher Education Personnel (CAPES) from Brazil for the financial support and to the Department of Chemistry of the Federal University of Paraná, Brazil, for the assistance in GC/MS analysis.

\section{REFERENCES}

Adams RP. 2017. Identification of essential oil components by gas chromatography/quadrupole mass spectroscopy. American Society for Mass. Texas, USA.

Alam MN, Bristi NJ, Rafiquzzaman M. 2013. Review on in vivo and in vitro methods evaluation of antioxidant activity. Saudi Pharm J 21: 143 - 152. https://doi.org/10.1016/j.jsps.2012.05.002

Amarante CB, Müller AH, Póvoa MM, Dolabela MF. 2011. Estudo fitoquímico biomonitorado pelos ensaios de toxicidade frente à Artemia salina e de atividade antiplasmódica do caule de aninga (Montrichardia linifera). Acta Amazonica 41: 431 - 434. https://doi.org/10.1590/S0044-59672011000300015

Apel MA, Lima MEL, Souza A, Cordeiro I, Young MCM, Sobral MEG, Suffredini IB, Moreno PRH. 2006. Screening of the biological activity from essential oils of native species from the atlantic rain forest (São Paulo - Brazil). Pharmacologyonline 3: 376 - 383.

Ayres MCC, Brandão MS, Vieira-júnior GM, Menor JCAS, Silva HB, Soares MJS, Chaves MH. 2008. Atividade antibacteriana de plantas úteis e constituintes químicos da raiz de Copernicia prunifera. Braz J Pharmacogn 18: 90 - 97. https://doi.org/10.1590/S0102-695X2008000100017

Baitello JB. 2001. Novas espécies de lauraceae para a flora brasileira. Acta Bot Bras 15: 445 - 450. https://doi.org/10.1590/S0102-33062001000300012

Banerjee A, Kunwar A, Mishra B, Priyadarsini KI. 2008. Concentration dependent antioxidant/pro-oxidant activity 
of curcumin. Studies from AAPH induced hemolysis of RBCs. Chem Biol Interact 174: 134 - 139. https://doi.org/10.1016/j.cbi.2008.05.009

Barbosa-Filho JM, Cunha RM, Dias CS, Athayde-Filho PF, Silva MS, Da-Cunha EVL, Machado MIL, Craveiro AA, Medeiros IA. 2008. GC-MS analysis and cardiovascular activity of the essential oil of Ocotea duckei. Braz J Pharmacogn 18: 37 - 41. https://doi.org/10.1590/S0102-695X2008000100009

Barros FJ, Costa RJO, Cesário FRAS, Rodrigues LB, da Costa JGM, Coutinho HDM, Galvao HBF, de Menezes IRA. 2016. Activity of essential oils of Piper aduncum Anf and Cinnamomum zeylanicum by evaluating osmotic and morphologic fragility of erythrocytes. Eur J Integr Med 8: 505 - 512.

https://doi.org/10.1016/j.eujim.2016.02.011

Betim FCM, Oliveira CF, Souza AM, Szabo EM, Zanin SMW, Miguel OG, Miguel MD, Dias JFG. 2019. Ocotea nutans (Nees) Mez (Lauraceae): chemical composition, antioxidant capacity and biological properties of essential oil. Braz J Pharm Sci 55: 1 - 10. https://doi.org/10.1590/s2175-97902019000118284

Brand-Williams W, Cuvelier ME, Berset C. 1995. Use of a free radical method to evaluate antioxidant activity. Food Sci Technol 28: 25 - 30. https://doi.org/10.3906/sag-1411-35

Brasil. 2010. Farmacopeia Brasileira. Agência Nacional de Vigilância Sanitária. ANVISA, Brasília, Brasil.

Brehm-Stecher BF, Johnson EA. 2003. Sensitization of Staphylococcus aureus and Escherichia coli to antibiotics by the sesquiterpenoids nerolidol, farnesol, bisabolol, and apritone. Antimicrob Agents Chemother 47: 3357 - 3360. https://doi.org/10.1128/AAC.47.10.3357-3360.2003

Brito AFR. 2009. Análise de variação sazonal e das atividades antifúngica e antimicrobiana em óleos essenciais de Ocotea porosa (Nees) Barroso e Nectandra megapotamica (Spreng.). Thesis, Institute of Chemistry, University of São Paulo, Brasil.

Brotto ML, Baitello JB, Cervi AC, Santos ÉP. 2010. Uma nova espécie de Ocotea (Lauraceae) para o Brasil. Rodriguésia 61: 57 - 60. https://doi.org/10.1590/2175-7860201061133

Brotto ML, Cervi AC, Santos ÉP. 2013. The genus Ocotea (Lauraceae) in Parana State, Brazil. Rodriguésia 64: 495 - 525. https://doi.org/10.1590/S2175-78602013000300004

Burt S. 2004. Essential oils: their antibacterial properties and potential applications in foods - a review. Int J Food Microbiol 94: 223 - 253. https://doi.org/10.1016/j.ijfoodmicro.2004.03.022

Carvalho EB, Borges ÉL, Carlos LMB, Silva MAM, Magalhães SMM, Gomes FVBAF, Carvalho MJC, Quixadá ATS, Pitombeira MHS. 2007. Efeito da bomba de infusão de soluções sobre o grau de hemólise em concentrados de hemácias. Rev Bras Hematol Hemoter 29: 149 - 152.

https://doi.org/10.1590/S1516-84842007000200013

Chan WK, Tan LTH, Chan KG, Lee LH, Goh BH. 2016. Nerolidol: A sesquiterpene alcohol with multi-faceted pharmacological and biological activities. Molecules 21: 1 - 40.

https://doi.org/10.3390/molecules21050529

Chaverri C, Cicció JF. 2005. Essential oil of trees of the genus Ocotea (Lauraceae) in Costa Rica. I. Ocotea brenesi. Int J Trop Biol 53: 431 - 436.

Chaverri C, Díaz C, Cicció JF. 2011. Chemical analysis of essential oils from Ocotea gomezii W.C. Burger and Ocotea morae Gómez-Laur. (Lauraceae) collected at Reserva Biológica Alberto M. Brenes in Costa Rica and their cytotoxic activity on tumor cell lines. J Braz Chem Soc 22: 741 - 745.

https://doi.org/10.1590/S0103-50532011000400018

Cicció JF, Chaverri C, Díaz C. 2009. Volatile compounds of Nectandra salicina (Lauraceae) from Costa rica and their cytotoxic activity on cell lines. Quim Nova 32: 417 - 420.

https://doi.org/10.1590/S0100-40422009000200028

CLSI [Clinical and Laboratory Standards Institute]. 2008. Methods for dilution antimicrobial susceptibility tests for bacteria that grow aerobically. M07-A8, Wayne, USA.

Da Silva JK, Da Trindade R, Moreira EC, Maia JGS, Dosoky NS, Miller RS, Cseke LJ, Setzer WN. 2017. Chemical diversity, biological activity, and genetic aspects of three Ocotea species from the Amazon. Int J Mol Sci 18: 1 - 15. https://doi.org/10.3390/ijms18051081

Damasceno CSB, Oliveira LF, Szabo EM, Souza ÂM, Dias JFG, Miguel MD, Miguel OG. 2017. Chemical composition, antioxidant and biological activity of Ocotea bicolor Vattimo-Gil (Lauraceae) essential oil. Braz J Pharm Sci 53: 1 - 8. https://doi.org/10.1590/s2175-97902017000417298

Destryana RA, Young DG, Woolley CL, Huang TC, Wu HY, Shih WL. 2014. Antioxidant and anti-inflammation 
activities of Ocotea, Copaiba and blue cypress essential oils in vitro and in vivo. J Am Oil Chem Soc 91: 1531 - 1542. https://doi.org/10.1007/s11746-014-2504-4

Garcez FR, Silva AFG, Garcez WS, Linck G, Matos MFC, Santos ECS, Queiroz LMM. 2011. Cytotoxic aporphine alkaloids from Ocotea acutifolia. Planta Med 77: 383 - 387. https://doi.org/10.1055/s-0030-1250401

Garrett R, Cruz RAS, Guerra MS, Gattuso M, Rocha L. 2007. Atividade antibacteriana do óleo essencial de Ocotea notata guiada pelo ensaio de toxidade sobre Artemia salina leach. Bol Latinoam Caribe Plant Med Aromat 6: 344 - 345.

Goren AC, Piozzi F, Akcicek E, Kiliç T, Çarikçi S, Moziolu E, Setzer WN. 2011. Essential oil composition of twenty-two Stachys species (mountain tea) and their biological activities. Phytochem Lett 4: 448 - 453. https://doi.org/10.1016/j.phytol.2011.04.013

Grecco SDS, Martins EGA, Girola N, De Figueiredo CR, Matsuo AL, Soares MG, Bertoldo BDC, Sartorelli P, Lago JHG. 2015. Chemical composition and in vitro cytotoxic effects of the essential oil from Nectandra leucantha leaves. Pharm Biol 53: 133 - 137. https://doi.org/10.3109/13880209.2014.912238

Guerrini A, Sacchetti G, Muzzoli M, Rueda GM, Medici A, Besco E, Bruni R. 2006. Composition of the volatile fraction of Ocotea bofo Kunth (Lauraceae) calyces by GC-MS and NMR fingerprinting and its antimicrobial and antioxidant activity. J Agric Food Chem 54: 7778 - 7788.

https://doi.org/10.1021/jf0605493

Hossan MS, Hanif A, Agarwala B, Sarwar MS, Karim M, Taufiq-Ur-Rahman M, Jahan R, Rahmatullah M. 2010. Traditional use of medicinal plants in Bangladesh to treat urinary tract infections and sexually transmitted diseases. Ethnobot Res Appl 8: 61 - 74.

Hsu HC, Yang WC, Tsai WJ, Chen CC, Huang HY, Tsai YC. 2006. $\alpha$-Bulnesene, a novel PAF receptor antagonist isolated from Pogostemon cablin. Biochem Biophys Res Commun 345: 1033 - 1038. https://doi.org/10.1016/j.bbrc.2006.05.006

Lapczynski A, Letizia CS, Api AM. 2008. Fragrance material review on cis-nerolidol. Food Chem Toxicol 46: 245 - 246. https://doi.org/10.1016/j.fet.2008.06.034

López-Alarcón C, Denicola A. 2013. Evaluating the antioxidant capacity of natural products: A review on chemical and cellular-based assays. Anal Chim Acta 763: 1 - 10. https://doi.org/10.1016/j.aca.2012.11.051

Manaargadoo-Catin M, Ali-Cherif A, Pougnas JL, Perrin C. 2016. Hemolysis by surfactants - A review. Adv Colloid Interface Sci 228: 1 - 16. https://doi.org/10.1016/j.cis.2015.10.011

Marques CA. 2001. Economic importance of family Lauraceae Linal. Floresta e Ambiente 8: 195 - 206.

Martínez JL, Torres R, Morales MA. 1997. Hypotensive effect of O-methylisothalicberine, bisbenzylisoquinoline alkaloid isolated from Berberis chilensis, on normotensive rats. Phytother Res 11: 246 - 248.

Mensor LL, Menezes FS, Leitão GG, Reis AS, Santos TC, Coube CS, Leitão SG. 2001. Screening of brazilian plant extracts for antioxidant activity by the use of DPPH free radical method. Phytother Res 130: 127 - 130. https://doi.org/10.1002/ptr.687

Meyer BN, Ferrigni NR, Putnam JE, Jacobsen LB, Nichols DE, McLaughlin JL. 1982. Brine shrimp: A convenient general bioassay for active plant constituents. Med Plant Res 45: 31 - 34.

https://doi.org/10.1055/s-2007-971236

Moraes PLR. 2005. Sinopse das Lauráceas nos estados de goiás e Tocantins, Brasil. Biota Neotropica 5: 1 - 18. https://doi.org/10.1590/S1676-06032005000300018

Moraes MM, Camara CAG, Silva MMC. 2017. Comparative toxicity of essential oil and blends of selected terpenes of Ocotea species from Pernambuco, Brazil, against Tetranychus urticae Koch. An Acad Bras Cienc 89: 1417 - 1429. https://doi.org/10.1590/0001-3765201720170139

Mosmann T. 1983. Rapid colorimetric assay for cellular growth and survival: Application to proliferation and cytotoxicity assays. J Immunol Methods 65: 55 - 63. https://doi.org/10.1016/0022-1759(83)90303-4

NIST [National Institute of Standards and Technology]. 1998. PC version of the NIST/EPA/NIH Mass Spectral Database.

Niksic H, Duric K, Sijamic I, Koric E, Kusturica J, Omeragic E, Muratovic S. 2019. In vitro antiproliferative activity of Melissa officinalis L (Lamiaceae) leaves essential oil. Bol Latinoam Caribe Plant Med Aromat 18: 480 - 491.

Pequeno NF, Soto-Blanco B. 2006. Toxicidade in vitro de plantas tóxicas: avaliação do teste de ação hemolítica. Acta Sci Vet 34: 45 - 48. https://doi.org/10.22456/1679-9216.15066

Boletín Latinoamericano y del Caribe de Plantas Medicinales y Aromáticas/506 
Pintore G, Usai ŁM, Bradesi P, Juliano C, Boatto G, Tomi F, Chessa M, Cerri R, Casanova J. 2002. Chemical composition and antimicrobial activity of Rosmarinus officinalis L. oils from Sardinia and Corsica. Flavour Fragr J 17: 15 - 19. https://doi.org/10.1002/ffj.1022

Prieto P, Pineda M, Aguilar M. 1999. Spectrophotometric quantitation of antioxidant capacity through the formation of a phosphomolybdenum complex: Specific application to the determination of vitamin E. Anal Biochem 269: 337 - 341. https://doi.org/10.1006/abio.1999.4019

Raut JS, Karuppayil SM. 2014. A status review on the medicinal properties of essential oils. Ind Crops Prod 62: 250 - 264. https://doi.org/10.1016/j.indcrop.2014.05.055

Sangwan NS, Farooqi AHA, Shabih F, Sangwan RS. 2001. Regulation of essential oil production in plants. Plant Growth Regul 34: 3 - 21. https://doi.org/10.1023/A:1013386921596

Santos AO, Ueda-Nakamura T, Filho BPD, Junior VFV, Pinto AC, Nakamura CV. 2008. Antimicrobial activity of Brazilian copaiba oils obtained from different species of the Copaifera genus. Mem Inst Oswaldo Cruz 103: 277 - 281. https://doi.org/10.1590/S0074-02762008005000015

Santurio JM, Santurio DF, Pozzatti P, Moraes C, Franchin PR, Alves SH. 2007. Atividade antimicrobiana dos óleos essenciais de orégano, tomilho e canela frente a sorovares de Salmonella enterica de origem avícola. Cienc Rural 37: 803 - 808. https://doi.org/10.1590/S0103-84782007000300031

Sharma P, Sharma JD. 2001. In vitro hemolysis of human erythrocytes - By plant extracts with antiplasmodial activity. J Ethnopharmacol 74: 239 - 243. https://doi.org/10.1016/S0378-8741(00)00370-6

Silva EBP, Matsuo AL, Figueiredo CR, Chaves MH, Sartorelli P, Lago JHG. 2013. Chemical constituents and cytotoxic evaluation of essential oils from leaves of Porcelia macrocarpa (Annonaceae). Nat Prod Comm 8: 277 - 279. https://doi.org/10.1177/1934578X1300800237

Sousa OV, Dutra RC, Yamamoto $\mathrm{CH}$, Pimenta DS. 2008. Estudo comparativo da composição química e da atividade biológica dos óleos essenciais das folhas de Eremanthus erythropappus (DC) McLeisch. Rev Bras Farm 89: 113 - 116.

Sylvestre M, Pichette A, Longtin A, Nagau F, Legault J. 2006. Essential oil analysis and anticancer activity of leaf essential oil of Croton flavens L. from Guadeloupe. J Ethnopharmacol 103: 99 - 102. https://doi.org/10.1016/j.jep.2005.07.011

Takaku S, Haber WA, Setzer WN. 2007. Leaf essential oil composition of 10 species of Ocotea (Lauraceae) from Monteverde, Costa Rica. Biochem Syst Ecol 35: 525 - 532. https://doi.org/10.1016/j.bse.2007.02.003

Veiga A, Toledo MGT, Rossa LS, Mengarda M, Stofella NCF, Oliveira LJ, Gonçalves AG, Murakami FS. 2019. Colorimetric microdilution assay: Validation of a standard method for determination of $\mathrm{MIC}, \mathrm{IC}_{50} \%$, and $\mathrm{IC}_{90} \%$ of antimicrobial compounds. J Microbiol Methods 162: 50 - 61. https://doi.org/10.1016/j.mimet.2019.05.003

Wright BS, Bansal A, Moriarity DM, Takaku S, Setzer WN. 2007. Cytotoxic leaf essential oils from neotropical Lauraceae: Synergistic effects of essential oil components. Nat Prod Comm 2: 1241 - 1244. https://doi.org/10.1177/1934578X0700201210

Yamaguchi KKDL. 2011. Estudos biológicos dos extratos e composição química dos oleos essenciais de espécies da família Lauraceae. Thesis, Institute of Chemistry, University of Amazonas, Brasil.

Van Der Werff H, Richter HG. 1996. Toward an improved classification of Lauraceae. Ann Missouri Bot Gard 83: 409 - 418. 